Jurnal Akuntansi dan Investasi, Vol. 19 No. 1, Hlm: 36-53 Januari 2018

Artikel ini tersedia di website: http://journal.umy.ac.id/index.php/ai

DOI: $10.18196 /$ jai.190190

\title{
The Institutionalization of Spending Review in Budgeting System in Indonesia
}

\begin{tabular}{l} 
Hendi Kristiantoro*; \\
Faculty of Economics \\
\hline A R T I C L E I N F O \\
\hline Article history: \\
received 02 Aug 2017 \\
reviwed 13 Aug 2017 \\
revised 17 Aug 2017 \\
accepted 07 Sept 2017 \\
Keywords: \\
Spending Review; \\
State Revenue and \\
Expenditure Budget; \\
New Institutional; \\
Government \\
Expenditure \\
\hline
\end{tabular}

\section{INTRODUCTION}

The Directorate General of Treasury as a unit under the Ministry of Finance responsible for the implementation of APBN requires an evaluation mechanism capable of measuring the efficiency and effectiveness level of government expenditures. Such mechanism is expected not just to be helpful to assess to what extent the government expenditure performance is, but also to be an input for the planning of following period's budget (Saputro, 2015). With this as a rationale, the Directorate General of Treasury since the implementation of 2012 Budget Year APBN has gradually begun to initiate the institutionalization of spending review.

In the Circular Letter of Director General of Treasury Number SE-12/PB/2016 on Spending Review Preparation, it is stated that spending review is a mechanism of measurement which emphasizes on the effectiveness, efficiency, and economicality of government expenditure use. This institutionalization of spending review is in line with Brugnon's (2013) opinion which says that spending review is based on the ideas of how to manage public expenditures and create rooms for saving. According to Robinson (2014), spending review is a process of adopting and developing steps for saving based on a systematic supervision on the expenditure budget baseline. Spending review is expected to measure the efficiency, effectiveness, and usefulness levels of government expenditure, and to identify any fiscal space potential.

In relation to fiscal space, its availability in APBN is a requirement to be able to ensure the continuance of life as a nation as well as to be the driver of people's economy. And when the government's vision and mission emphasize on more productive expenditure portions, especially for infrastructure constructions, APBN should have adequate fiscal space availability. According to Schick (2009), fiscal space is the availability of financial resources to support the government's policy initiative through budgets and budgetrelated decisions. Meanwhile, Heller (2005) defines fiscal space as the availability of space which enables the government to provide resources to achieve certain goals without endangering and putting aside the fiscal sustainability.

In the budget planning practice, the provision of fiscal space has been a particular difficulty. This is because even before its planning process, APBN has been fragmented by the mandatory spending provision. Mandatory spending is the mandate of regulations of law to allocate an expenditure budget at a certain percentage amount. Mandatory spending in APBN includes the provision to allocate $20 \%$ of the state expenditure for education, a minimum of $26 \%$ of net domestic revenue for General Allocation Fund or Dana Alokasi Umum (DAU), a minimum of 
$5 \%$ of the total APBN (excluding expenditures for employees of Ministry of Health) is allocated for government health budget, and finally a budget allocation from Central Government which is alloted directly to villages is determined at $10 \%$ of and beyond the Regional Transfer fund gradually.

The average proportion of mandatory spending to state expenditures within 2010-2014 period has reached $79.3 \%$. This obligatory expenditure has resulted in limited fiscal space, hence when the revenue target cannot be met, the budget deficit will enlarge. This, in turn, will force the Government to increase the budget financing or cut the expenditure budget of Ministry/State Institution.

The process of institutionalizing spending review is a form of organizational change. This is because of the change in the mindset of those parties related to the process. The social environment where an organization is in will influence the organization's structure. In response to changes, the organization should adapt to its environment (Meyer and Rowan, 1977). Jones (2001) suggests that in its change process, the organization will decide what elements within itself to be changed. DiMaggio and Powell (1983) emphasize that process and structure changes tend to lead those organizations in the similar field to be uniform. It makes an organization legitimates certain ways in terms of how they organization themselves (Sofyani and Akbar, 2013).

The institutionalization process of spending review in Indonesia does not stand alone. The external influence, particularly other countries which have practiced spending review plays some role too. The annual meeting held by Organization for Economic Coorporation and Development (OECD) in Paris in November 2011 which was attended by the Directorate General of Treasury officials had been one initial trigger of spending review institutionalization process by the Ministry of Finance. In this meeting, Proposal for Analysis of Spending Reviews is presented, explaining the fundamental concept of spending review, such as the typology, characteristics, and governance practiced in the member states of OECD (Rahmayanti, 2013).

DiMaggio and Powell (1983) state that institutional environment will influence an organization. This notion has been the basic for applying new institutional theory. Any idea, logic, dan practice with some influence are regarded as valid, feasible, and then institutionalized to be an integral part of the organization. There are three forms of isomorphic institutional pressure, namely mimetic, coercive, and normative. These three institutional pressures can influence organization changes either collectively or independently.

Empiric research using DiMaggio and Powell's (1983) new institutional theory as its basis is conducted by Amirya et al. (2011) which studies the development and implication of budget and accounting systems of General Service Board of Brawijaya University. The study successfully describes the occurence of institutional isomorphism symptoms. The most dominant isomorphism type is coercive isomorphism which takes place when there is an urge from the law regulations which is binding and enforced by the Central Government. Furthermore, the isomorphism type of mimetic nature can be seen from the process of adopting a system which has been implemented by other state universities. Meanwhile, the normative type occurs because of the involvement of professional consultant in its institutionalization process.

Adhikari et al. (2013) study by comparing the implementations of public sector accounting reform along with the roles played by external environmental factors influencing its institutionnalization process in Nepal and Sri Lanka. The research finds that the public sector accounting reform in both countries are influenced by the international accounting development as a form of institutional pressure. The institutionalization process in Nepal is done because of the efforts to obtain legitimation from World Bank and Asian Development Bank (coercive), the adoption of accounting standards from IPSAS (mimetic), and the involvement of government employees and professional accountant (normative). Meanwhile, in Sri Lanka the institutionalization process is influenced by normative factors where many people of Sri Lanka who study accounting in England (and its colonies), and mimetic factors since Sri Lanka wants to emulate the budgeting practice the western countries think better. The research on institutionalization process of social accounting in state-owned forestry firm Perum Perhutani of Blitar also shows that public organization cannot be separated from the influence of its environment (Nurdiwaty et al., 2014). The coercive and normative isomorphism types take place in the institutionalization process of social accounting in this Perum Perhutani.

Using previous studies as its bases, this research uses new institutional theory to understand the institutionalization process of spending review by the Directorate General of Treasury. The 
Directorate General of Treasury is a unit under the Ministry of Finance responsible for implementing APBN. It means the performance of Directorate General of Treasury also influences the performances of all Ministries/State Institutions with some budget portions in APBN. It is expected that this research would be able to give better insight into how institutional pressure occurs from both external and internal factors of the organization. This study also identifies the existing conditions in the Directorate General of Treasury along with its institutional environment.

Later on, the results of this research are expected to enrich the scientific perspectives and theory development in relation to spending review in the budgeting systems in Indonesia, as well as to serve as considerations for the Directorate General of Treasury as the competent authority in the implementation of spending review, hence it can find the strengths and or weaknesses of the processes which have been implemented to prepare their remedial steps in the future.

\section{LITERATURE REVIEW AND FOCUS OF STUDY}

\section{New Institutional Theory}

An organization's existence is highly dependent on the public trust that this organization is a legitimate and worth-supporting entity (Meyer and Rowan, 1977). To manifest such an existence, the organization tends to be adaptive to external or social expectation surrounding its existence (DiMaggio and Powell, 1983). This notion has been the basic for applying new institutional theory. Any idea, logic, dan practice with some influence are regarded as valid, feasible, and then institutionalized to be an integral part of the organization.

Any public organization striving to obtain legitimacy will tend to have similarities or isomorphism with other public organizations (DiMaggio and Powell, 1983). Isomorphism is the symptom where a public organization becomes similar to its environment. The social reality allows the formation of similar technical dependence and exchange, and structural construction (Meyer and Rowan, 1977). Hawley (1968) defines isomorphism as a process where a unit in a population tend to resemble other units in responding to similar environmental situation and condition.
Isomorphism can be shaped by three exogenous factors, namely coercive, mimetic, and normative (Lippi, 2000). Coercive isomorphism occurs when the organization receives pressure of forcible and binding natures from the regulations of law. Mimetic isomorphism is an institutionnalization process which is based on emulation or imitation of other organizations which have successfully implemented a system (Lippi, 2000). Mimetic isomorphism occurs when the organization experiences goal ambiguity or has not determined any clear-cut goals (Wijaya and Akbar, 2013), hence it will emulate or imitate the goals of other organizations (Sofyani and Akbar, 2013). As to normative isomorphism, it is based on the drive from inside the institution to make some changes in a professional manner when the organization in adopting a concept is based on the involvement of consultants or team as professionals with some expertises in their fields.

The isomorphism process can also occur due to endogenous factors, such as actors, institutions, systems of thinking and languages which have existed in the organization (Lippi, 2000). According to Lippi (2000), these endogenous factors have cause the institutionalization process to be of bottom-up nature called as Isomorphism. Isomorphism is embodied through the re-interpretation of influences of foreign elements or re-contextualization by public organizations (Amirya et al., 2011).

\section{Spending Review}

The global economic crisis hitting most European countries and the United States since the first half of 2000s decade has forced many governments to step into a new era of cutting their public expenditures and budget streamlining policy (Pollitt and Bouckaert, 2004). This new era also becomes the beginning of massive use of spending review term as one of those solutions available to the crisis. Nevertheless, until recently no one definite meaning has been agreed upon of the spending review definition (Agasisti et al., 2015).

Hawkesworth and Klepsvik (2013) suggest that spending review is the assessment of strategic orientation of a program and or expenditure efficiency which is widely used to reduce and reallocate expenditure budgets. Robinson (2014), based on studies in member states of Organisation for Economic Co-operation and Development (OECD), says that spending review serves as a 
process of adopting and developing saving steps based on a systematic supervision on the expenditure budget baseline. In this case, spending review is used as a tool for controlling the government's aggregate expenditure level and to enhance the determination of expenditure priority. Brugnon (2013) concludes that the core of varied definition of spending review lies in the idea about how to manage public expenditures and create spaces for saving.

Spending review is a tool for implementing fiscal reform, particularly it is used to improve the availability of fiscal space through the cutting and re-allocation of budget (Hawkesworth and Klepsvik, 2013). Based on Robinson's (2014) typology, spending review can take the forms of efficiency review and or strategic review. Efficiency review focuses on increasing savings by referring to budget efficiency, i.e. providing services in equal number and at equal quality, yet at the lowest possible costs. Meanwhile, the strategic review's steps of saving are reached by reducing government services as well as cutting the amount of transfer payment. Pollitt (2010) defines strategic review as a strategic prioritization with a technical saving which allow the government to reduce some portion or even remove the entire budget of a program for it is proven ineffective, while on the other hand the government increases the portion of other programs because they are found more effective in providing benefits to the people.

Based on the background, theoretical review, and previous studies, this research then focuses on trying to answer the following problem formulation (PF):

PF: How is the institutionalization process of spending review in budgeting systems in Indonesia from the perspective of new institutional theory?

\section{RESEARCH METHOD}

This is case study-based interpretive qualitative research. Yin (2013) defines a case study as an empirical approach which observes phenomena within real-life context, especially when the borders between phenomena and their contexts cannot be clearly defined. Case studybased research, as compared to some other nonmainstream approaches, is the most-structured approach, with well-mapped steps, and clear measurement criteria (Basuki, 2016).
This research is exploratory, where the researchers endeavors to explore and build the phenomena under study in the effort of answering the previously formulated problem (Basuki, 2016). According to Arikunto (2006), exploratory research aims at extensively exploring the causes or matters influencing the occurence of something. The researcher's consideration for using exploratory case study approach is that the studied phenomena include values, cultures, and norms in an organizational structure or other factors which drive the institutionalization process of spending review.

This research's object is the institutionalization process of spending review in the budgeting systems in Indonesia. Based on Circular Letter of Director General of Treasury No. 12 Year 2016 on the Spending Review Drafting, spending review is a review of central government expenditure (APBN) from the value for money perspective of its use which include expenditure effectiveness, efficiency, and economicality. The review at central level is performed by the Budget Implementation Directorate and at regional level by the Regional Office of Directorate General of Treasury.

The informants in this research are those related to the institutionalization process of spending review. There are 5 informants in total, four of whom are officials and executing officers at the Budget Implementation Directorate and one informant is official at the Regional Office of Directorate General of Treasury of East Java Province. These officials and executing officers at the Budget Implementation Directorate are selected because of their involvement in formulating the spending review concept, developing the review method, and implementing the review procedure at central level. The selection of an official at Regional Office of Directorate General of Treasury of East Java Province as one informant is intended to obtain a picture of review process at regional level.

Based on the provisions of Circular Letter of Director General of Treasury No. 12 Year 2016 on Spending Review Drafting, the Regional Office of Directorate General of Treasury is not involved in the process of drafting the concept and development of spending review framework which is the domain for the Budget Implementation Directorate. The involvement of Regional Office of Directorate General of Treasury in the flow of spending review process is limited to its implementation at regional level. The list of 
officials and employees serving as the informants in this research is shown in Table 1.

The interviews with informants 1 and 2 were held on June 19, 2017. The interviews with informants 3 and 4 were held on June 20, 2017.
The interview with informant 5 was held in two occassions, namely on July 11, 2017 and July 18, 2017. These interviews use a question guideline as presented in table 2.

Table 1. List of Research Informants

\begin{tabular}{|c|c|c|c|}
\hline Informant & Initial & Position & Reason for being Chosen as Informant \\
\hline Informant 1 & TS & $\begin{array}{l}\text { Chief of Coordination } \\
\text { Section PA III }\end{array}$ & $\begin{array}{l}\text { 1. Is part of the core team for formulating spending } \\
\text { review concept and methodology established by } \\
\text { the Directorate General of Treasury } \\
\text { 2. Is part of the spending review development team }\end{array}$ \\
\hline Informant 2 & SD & $\begin{array}{l}\text { Executing Officers of } \\
\text { Coordination Section PA } \\
\text { III }\end{array}$ & Is part of the spending review development team. \\
\hline Informant 3 & AS & $\begin{array}{l}\text { Executing Officers of } \\
\text { Section PA II }\end{array}$ & Performing review procedure at central level \\
\hline Informant 4 & HA & $\begin{array}{l}\text { Executing Officers of } \\
\text { Section PA III }\end{array}$ & Performing review procedure at central level \\
\hline Informant 5 & $\mathrm{EC}$ & $\begin{array}{l}\text { Chief of Budget Guidance } \\
\text { Section I of Regional } \\
\text { Office of East Java DJPB }\end{array}$ & $\begin{array}{l}\text { Performing review procedure at regional level of } \\
\text { East Java Regional Office }\end{array}$ \\
\hline
\end{tabular}

Table 2. Interview Question Guidelines

\begin{tabular}{|c|c|c|}
\hline $\begin{array}{l}\text { Mapping according to } \\
\text { New Institutional Theory }\end{array}$ & Question & Informant \\
\hline \multirow{3}{*}{ Coercive } & $\begin{array}{l}\text { What is the background for implementing the institutionalization } \\
\text { process of spending review in Indonesia? }\end{array}$ & 1 \\
\hline & $\begin{array}{l}\text { What are the goals of implementing the spending review in } \\
\text { Indonesia? }\end{array}$ & $1 \& 2$ \\
\hline & $\begin{array}{l}\text { What is the role played by OECD in the institutionalization } \\
\text { process of spending review in Indonesia? }\end{array}$ & $1 \& 2$ \\
\hline \multirow{3}{*}{ Mimetic } & $\begin{array}{l}\text { How is the process of formulating initial spending review concept } \\
\text { in Indonesia? }\end{array}$ & $1 \& 2$ \\
\hline & $\begin{array}{l}\text { How is the process of determining the scope of spending review } \\
\text { and review mechanism? }\end{array}$ & $1 \& 2$ \\
\hline & $\begin{array}{l}\text { Is there any imitation of review mechanism from the spending } \\
\text { review practice which has been performed by other countries? }\end{array}$ & $1 \& 2$ \\
\hline \multirow{5}{*}{ Normative } & $\begin{array}{l}\text { How is the response of leaders in the Ministry of Finance in } \\
\text { relation to the institutionalization process of spending review? }\end{array}$ & $1 \& 2$ \\
\hline & $\begin{array}{l}\text { What is the role played by and how is the involvement of leaders } \\
\text { in the Ministry of Finance in the institutionalization process of } \\
\text { spending review? }\end{array}$ & $1 \& 2$ \\
\hline & $\begin{array}{l}\text { Are there any professional consultants involved in the } \\
\text { institutionalization process of spending review? }\end{array}$ & $1 \& 2$ \\
\hline & $\begin{array}{l}\text { How is the process of internalizing spending review in the review } \\
\text { technical executors at central and regional levels? }\end{array}$ & $1,2,3,4,5$ \\
\hline & $\begin{array}{l}\text { Is there any problem or difficulty encountered in the } \\
\text { implementation of review procedure? }\end{array}$ & $3,4,5$ \\
\hline
\end{tabular}




\section{RESULT AND DISCUSSION}

\section{Realizing High-Quality Expenditure in Fiscal Challenge Era}

In the midst of the world's economic stagnancy, the national economic growth has been too dependent on the government's fiscal policies. The formulation of fiscal policies which is embodied, among other things, in the allocation of expenditure in APBN should be credible by taking into account the prioritized and productive sectors. Even if the portion of government expenditure's contribution to GDP is $14 \%$ on average (Budget Implementation Directorate, 2017), the impact of this government expenditure can stimulate economic activities in general. Therefore, this government expenditure should be allocated in a high quality manner so that it can promote an inclusive economic growth, maintaining economic and financial stabilities and, improving people's welfare and providing social protection, as well as maintaining external balance.

The problem is that to realize a high-quality expenditure has never been easy. The Budget Implementation Directorate as the Echelon I unit of Directorate General of Treasury responsible for performing the monitoring and evaluation function of budget implementation finds at least three government expenditure problems.

The first one is fiscal capacity limitations. Fiscal capacity is a country's financial capability collected from legitimate funding sources under regulations of law, such as from tax and Non-Tax State Revenue or Penerimaan Negara Bukan Pajak (PNBP) sectors. This fiscal capacity ensures the fulfillment of fiscal needs which are the needs for funding the state expenditures in order to pay their liabilities such as debt principal and interest payments and to perform their governmental functions, policies, and governmental obligations such as health, education and infrastructure service provisions, debt interest payment and principal installment, as well as subsidies (Wardhana et al., 2014).
In the APBN budgeting practice, the state revenues are frequently inadequate. It even worsens when the government with their Nawacita (Nine Priorities) program expansively promote the constructions of many infrastructures, leading to the increased fiscal needs. The realization of APBN revenues within the Budget Years 2012 through 2016 has actually been increasing from IDR1,338.1 Trillions into IDR1,555.2 Trillions. Yet, such increase becomes less significant since the expenditure allocation keeps increasing at the same time. Based on the percentage of revenue realization as compared to the target predetermined in Revised State Revenue and Expenditure Budget (APBN-P), it actually decreases from $98.52 \%$ in 2012 to merely $87.06 \%$ in 2016 . The list of state revenue realizations in the last four Budget Years is presented in table 3.

This less optimal state revenue realization is mainly influenced by the low growth rate of tax sector. The pressure from global economic state of affairs which leads to economic lethargy and stagnancy has some influence on the domestic economic activities, hence the growths of ValueAdded Tax (PPN) and Import and Export Duties decrease. The tax amnesty program which is expected to stimulate tax revenue did not yield satisfactory results when the revenue from taxes has actually been the main contributor to the state revenue at a portion of $77 \%$ on average of the total APBN revenues each year.

With such fiscal capacity limitations, the government's fiscal space to maneuver with productive expenditure allocation has automatically lessened. The fiscal space of APBN between 2012 and 2016 Budget Years ranged merely at 4-5\% of GDP. With this limited fiscal space, the government is far from flexible in issuing economic policies through expenditure allocation. The second one is the provisions of mandatory spending. Mandatory spending is the mandate of regulations of law to allocate an expenditure budget at a certain percentage amount. This mandatory spending in APBN includes the provision to allocate $20 \%$ of the state expenditure for education, a minimum of

Table 3. State Revenue Realization Report for Fiscal Year 2012-2016

\begin{tabular}{lccccc}
\hline & 2012 & 2013 & 2014 & 2015 & 2016 \\
\hline Realization & $1.338,1$ & $1.438,9$ & $1.550,7$ & $1,504,5$ & $1.555,2$ \\
APBN & $1.311,4$ & $1.529,7$ & $1.667,2$ & $1.761,7$ & $1.822,5$ \\
APBN-P & $1.358,2$ & $1.502,0$ & $1.635,4$ & $1.761,7$ & $1.786,3$ \\
\% Realization & $96,52 \%$ & $95,80 \%$ & $94,82 \%$ & $85,40 \%$ & $87,06 \%$ \\
\hline
\end{tabular}

Source: I-Account, Indonesia Ministry of Finance 
$26 \%$ of net domestic revenue for General Allocation Fund (DAU), a minimum of $5 \%$ of the total APBN (excluding expenditures for employees of Ministry of Health) is allocated for government health budget, and finally a budget allocation from Central Government which is alloted directly to villages is determined at $10 \%$ of and beyond the Regional Transfer fund gradually.

The average proportion of mandatory spending to state expenditures within 2012 to 2016 Budget Years period has reached $72.86 \%$. This obligatory expenditure has resulted in limited fiscal space, hence when the revenue target cannot be met, the budget deficit will enlarge. This, in turn, will force the Government to increase the budget financing or cut the expenditure budget of Ministry/State Institutions. The detail of state expenditure, obligatory spending, and fiscal space of 2012 through 2016 Budget Year can be seen in Table 4 .

The third one is unevenly distributed expenditure allocation. The expenditure allocation for Ministries/State Institutions in APBN for 2012 to 2016 Budget Year period continues to increase. In 2012 APBN the expenditure allocation for Ministries/State Institutions was IDR603.7 Trillions and increased to IDR929.4 Trillions in 2016 APBN. However, from the expenditure types, from 2012 to 2016 Budget Years, the proportion of two expenditure types had increased, namely personnel and goods expenditures. Meanwhile, two other expenditures, namely capital expenditure and social assistance expenditure decreased. The concentration of expenditure allocation increases pn personnel and goods expenditure types indicates the increasing tendency of expenditures of routine and operational natures. This shows that the expenditure allocation cannot entirely be aligned yet with the productive expenditure policies focusing on infrastructure and social expenditures. In other words, the efficiency of personnel and goods expenditure allocations is still highly required.

To deal with these three expenditure problems, the government should ensure that the expenditure they allocate is actually of high quality. The parameters commonly used to measure the quality of expenditures are value for money. There are three elements to value for money, namely economical, effective, and efficient. Economical means the cost is minimized to produce certain output. Effective means an outcome or impact is reached after the output is formed. Efficient means the input is minimized in producing certain output. One way or mechanism to ensure that the value for money of government expenditures is fulfilled is through spending review.

Table 4. State Spending, Mandatory Spending, and Fiscal Space for Fiscal Year 2012-2016

\begin{tabular}{lccccc}
\hline Item & 2012 & 2013 & 2014 & 2015 & 2016 \\
\hline State Spending & $1.491,41$ & $1.65150,56$ & $1.777,18$ & $1.806,51$ & $2.2082,94$ \\
Mandatory Spending & $1.125,43$ & $1.203,01$ & $1.342,81$ & $1.246,25$ & $1.487,65$ \\
$\quad$ A. Government Employee & 197,86 & 221,68 & 243,71 & 281,14 & 342,44 \\
$\quad$ Spending & 100,51 & 113,03 & 133,44 & 156,01 & 191,21 \\
$\quad$ B. Interest Payment & 346,42 & 355,04 & 391,96 & 185,97 & 177,75 \\
$\quad$ C. Subsidy & 480,64 & 513,26 & 573,7 & 623,13 & 776,25 \\
$\quad$ D. Transfer to Local & 365,98 & 447,55 & 434,37 & 560,26 & 595,29 \\
$\quad$ Government & $8.241,90$ & $9.084,00$ & $10.542,00$ & $11.540,80$ & $12.117,84$ \\
Fiscal Space & & & & & \\
Gross Domestic Income & $18,10 \%$ & $18,17 \%$ & $16,86 \%$ & $15,65 \%$ & $17,19 \%$ \\
(GDI) of Indonesia & $13,65 \%$ & $13,24 \%$ & $12,74 \%$ & $10,80 \%$ & $12,28 \%$ \\
State Budget toward Local & $4,44 \%$ & $4,93 \%$ & $4,12 \%$ & $4,85 \%$ & $4,91 \%$ \\
Government Budget & Mandatory Spending for GDI & $72,88 \%$ & $75,56 \%$ & $68,99 \%$ & $71,42 \%$ \\
Fiscal Space toward GDI & Mandatory Spending toward & $75,46 \%$ & & & \\
Total Spending & & &
\end{tabular}

Source: Procurement of Goods / Services Policy Department (LKPP) 2012 s.d 2015, APBN-P 2016 
Preliminary Initiation of Spending Review: Influence of OECD and Gradual Development Review Methodology

Foremer Director General of Treasury, Agus Supriyanto, in an interview with the editorial crew of Treasury Magazine (Edition I/2013 issue March 2013) explains about the starting point of spending review initiation by the Directorate General of Treasury. It began with the participation in OECD Senior Budget Officials Network on Performance and Results in Paris in November 2011 which discussed about budgeting and treasury. One of the issues discussed there was spending review. At that time, spending review was elaborated as a solution to deal with the fiscal crisis in the form of budget deficit and increased government's debts which were hitting the member states of European Union. In OECD's perspective, spending review was intended to find saving which could then be used to reduce the government's financial deficit and debts.

Once they returned from this OECD conference, the delegation of Directorate General of Treasury made a report and recommendation related to spending review to the Finance Minister (Agus Martowardojo). The Finance Minister welcomed these report and recommendations. $\mathrm{He}$ then instructed the implementation of spending review in Indonesia along with special message: "Just begin with the simple yet concrete ones and there has to be something done". This was the beginning of institutionalization of spending review by the Directorate General of Treasury.

This role played by OECD in the preliminary initiation of spending review is confirmed by informant 1 . However, this influence is limited to initial influence which drives the implementation of spending review in Indonesia. Informant 1 suggests the following:

“... It was from OECD meeting. Those who were present there, some of them were from us. Well, we were represented. From then on they merely endorsed that spending review was required to make the state expenditure efficient. Well, it was then brought to Indonesia. When we got our hands on it, we worked on its methodology ourselves. Because during the OECD report, someone just said "Well, it seems we needs spending review".

OECD through both its international official forums and OECD Journal On Budgeting was actually concerned about the development and distribution of notions related to public budgeting. OECD Journal On Budgeting is a publication specifically addressed to policy makers, bureaucrats, and researchers particularly those focusing on the field of public budgeting. Through this journal it is possible for the exchange of budgeting system best practices among its member states. Informant 1 then emphasizes that the spending review methodology built by the Directorate General of Treasury did not immediately follow the practices in those member states of OECD. This fact is stated as follows:

“...within OECD's context it means state expenditure efficiency. We then took another step forward into specifying it to government expenditure efficiency. In this case, it's the Central Government. Later, we specified it even further into Minsitry/Institution's expenditure efficiency - the logic is that when we talked about central government expenditure it was not just Ministry/State Institution's expenditure. That's what we did. About its metodolhogy, we just did what we could. We did metani (literally: lice removal combing) first during its initiation. What do you call metani? Combing. Combing (or sorting) the expenditures we thorugh inefficient. Only then it was escalated to the minister. From the minister it was escalated to the cabinet meeting. However, basically the methodology keeps on developing."

The transcript above shows that the actors playing the role in drafting the spending review methodology in Indonesia did not abruptly adopt the spending review methodology from the practices which have been implemented by other countries. They absorbed knowledge from the outside, studied it, then independently formulate the methods they thought suited the budgeting system characters and needs in Indonesia. As the Finance Minister's message said which instructed the review in a simple way, the term used by this informant to explain the review mechanism at the beginning of its initiation was "metani". "Metani" is a Javanese term which means "to comb". It means, the review process was done by combing (or sorting) the data manually one at a time.

In relation to this initial methodology, Former Director General of Treasury, Agus Supriyanto, explains as follows:

“... so, we looked at their efficiency, then we checked whether or not some were 
duplicated. Then, we checked were there any budget allocations for a program the allocation of which was just for one year, the program had actually finished yet its budget nemplok (remained) there. Well, it was indeed wasteful. Thus, I reviewed three things. The first one was inefficiency, the second was duplication, and the third one was einmalig. I borrow Dutch term for a one-shot activity." (Treasury Magazine, Edition I/2013)

The decision to not adopt immediately the methodology practiced in other countries, rather deciding to build this methodology gradually is explained by Informant 2, through his information below:

"The spending review in Indonesia was indeed a little bit different, slightly different from, for example the one in UK. The spending review in UK looked at things as a whole, this was a program like that. Would this program be appropriate, what about its allocation, should we increase or decrease it, to what extent should we decrease it, it had been fixed that way at any rate. Well, we could not do that just yet. So, the steps we took was indeed one at a time."

Spending review methodology in its simple form started to be tested in 2012. The data used were limited from one hundred and seven working units in ten Ministries/State Institutions. Through these data, some expenditure inefficiency and program/activity duplications were found. The goods expenditure inefficiency in 107 working units serving as the data sample objects had reached $15.29 \%$. As to the capital expenditure inefficiency in the same data sample, it had reached $17.17 \%$.

The methodology development kept on rolling. In 2013 the spending review was performed to twenty Ministries/State Institutions which obtained the greatest expenditure budget allocation. In 2014, the review was expanded to include all Ministries/State Institutions with many vertical units and varied characteristics. The conservatism principle in performing the review was prioritized. Any doubtful finding was sidelined. Hence, the findings presented were those actually strongly indicated as inefficient. In addition, the spending review results were also confirmed to the relevant Ministries/State Institutions to keep the spending review results valid.

\section{Spending Review: The Puzzle Piece Complementing APBN Management}

Spending review is a mechanism of measuring the expenditure quality which emphasizes on the effectiveness, efficiency, and economicality of government expenditure usage (APBN). Spending review is required to ensure that the government expenditures can be of high quality. Former Director General of Treasury, Agus Supriyanto, mentions one reason why spending review is needed in Indonesia:

"The point is that, why do we need to implement spending review in Indonesia. Our budget development, its size increases incredibly. Let's take as an example our 2005 budget. Our budget at that time at a maximum was 500 s trillions, in 2012 itr increased to 1,600 trillions. It increased three folds. The same applied to the budget for education and health sectors. Their budgets increased rapidly several folds. For elementary education, the increase was enormous. However, this increase was not followed by rapid development of Indonesian people's life quality, as reflected in the Human Development Index or Indeks Pembangunan Manusia (IPM). When we talk specifically about the 2005 to 2011 IPMs, the changes were average. There were no fairly significant improvements which were influenced by the substantial increase in the budgets. The same also applied to the budget for education sector which I compared to the education sector index. The human life quality index from education sector was mediocre, yet its budget increased quite significantly. It also happend to health sector. It means, the money we spent which increased up to five folds did not generate the outcome which was proportional to the rupiah value increase." (Treasury Magazine, Edition I/2013)

The transcript above shows the important role played by spending review to measure the government expenditure performance. Through spending review, the government could find out that the expenditure budget allocation they tried so hard to fulfill by optimizing all sources of revenues, including loan financing, did not actually deliver the expected outcomes. The continuously increasing budget posture did not directly proportional to the improvement of human life quality. It was ironic considering that improving human life quality was actually one of fundamental goals of life as a nation. 
Informant 1 explains further the role of spending review in measuring government expenditure performance. He says that through spending review, the government consciously correct themselves and realize a form of budgeting transparency. Spending review is a government statement that there is an expenditure inefficiency, hence it should be corrected. This is a form of the government's responsibility for the state finance it is managing. Informant 1's explanation in detail is as follows:

\begin{abstract}
"So, this spending review is actually a government statement. It is the government statement about efficiency. Spending review is actually a form of government self-evaluation. That is the point of spending review, a structure reform in the government. Since the government corrects itself that there is an inefficiency within itself. And the government tries to remedy this inefficiency. Usually, only outsiders will criticize, e... who was it? FITRA (Forum Indonesia Untuk Transparansi Anggaran or Indonesian Fourm for Budget Transparency) that's right, what is this.. inefficient, inefficient, inefficient... well, guess what now we do it ourselves.”
\end{abstract}

Spending review also discusses the technical aspects in the implementation of APBN and tries to identify the options available for saving which can be implemented through budget. When the Finance Minister decides to cut the expenditure budget for Ministries/State Institutions at IDR65 Trillions in 2016 Budget Year, one of the reference for doing so is the results of spending review. The budget cutting is done as an adjustment from the expenditure side in order to maintain the deficit at a level which would not cause any crisis to the trust to APBN. The cutting is performed to the expenditure posts indicated as inefficient, particularly from official travel and consignment activity posts. Informant 1 explains as follows:

"Well, in this case, we did spending review starting from November, since DIPA was issued. In that November 2015, DIPA 2016 had been issued. It was at that time that we began to perform spending review until the beginning of 2016. We processed it. Done, we released it. Jerr... Please note, the goal of spending review is budgeting improvement and to be an input for APBN-P. The 2015 APBN $\mathrm{P}$ was made in March. Or usually this APBN-P is done (the discussion) in, like today, in the mid-year, in semester. Right? Now, from then on from February or January the results of spending review were issued to be considerations, to be considerations of APBN-P for cutting in that year.”

Within the APBN cycle, the Directorate General of Treasury provides the results of spending review to be inputs for preparing the working plans of Minsitries/Institutions in a trilateral meeting between Ministry of Finance, National Development Planning Agency or Badan Perencanaan Pembangunan Nasional (Bappenas), and Minsitries/ Institutions. In accordance with Ministerial Regulation of Finance No. 234/ PMK.01/2015 the Ministry of Finance in that trilateral meeting is represented by the Budget Directorate General. The use of spending review results as considerations in the trilateral meeting surely requires synergy between the three parties (Budget Directorate General, Bappenas, Ministries/State Institutions) and the Directorate General of Treasury, to allow the APBN planning and budgeting processes to produce a credible APBN.

Within the Performance-Based Budgeting framework, the strategic role of spending review occurs when the information produced and presented from it can be used in making decisions on budget planning (Parhusip, 2017). Hawkesworth and Klepsvik (2013) include spending review as a component of PBK. It is intended to constantly review the suitability and effectiveness of a program and or activity which are in progress and use the performance information to help identify a program and or activity whose budget can be cut to increase the fiscal space availability.

From its analysis perspective, spending review can actually be similar to evaluation or analysis on other budget implementations. As we already know, World Bank also has a expenditure review project called Public Expenditure Review. Fiscal Policy Agency or Badan Kebijakan Fiskal (BKF) is also preparing form of government expenditure analysis. Meanwhile, based on the Presidential Decree or Keputusan Presiden (Keppres) Number 20 Year 2015 concerning Evaluation and Supervsory Team for the Realization of State Revenue and Expenditure Budget and Regional Revenue and Expenditure Budget, the president forms a Evaluation and Supervsory Team for the Realization of APBN 
and APBD ${ }^{1}$ (TEPRA). TEPRA is tasked to evaluate and facilitate the settlement of obstacles occuring in the way of the Central and Local Governments' budget and program realization. However, what distunguish spending review from those programs is that onbly spending review institutionally underlies the allocation of budget in APBN. In other words, only spending review serves a function which is bound to APBN.

\section{Spending Review and Strengthening of Institutional Function of Directorate General of Treasury}

Upon the implementation of institutional transformation of the Ministry of Finance, one of fundamental changes made is making the organizational structure more fit for purpose and effective. This is to allow the organizational construction within the Ministry of Finance to function effectively and efficiently in aligning their visions and mission and integrating their organizational strategy plan.

Within the budgeting context, the authority for planning and implementing budgets is separated. The process of DIPA drafting and DIPA revision which previously involve the Budget Implementation Directorate under the Directorate General of Treasury is handed over to the Directorate General Anggaran (DJA). The Budget Implementation Directorate focuses on the budget implementation, including giving objective analysis in the monitoring and evaluation functions. This authority shift is found to indirectly promote the institutionalization of spending review. Below is the explanation from Informant 2:

\begin{abstract}
"Historically, it was because the Budget Implementation (Budget Implementation Directorate) changed. DIPA used to be here, even dealing with DIPA. From my perspective, its main tasks were two: DIPA and making provisions of regulations. As for now, the provisions of regulations remain, the same. It was in Budget Implementation Analysis and Development Sub-directorate. Their main task of making DIPA had been transferred to DJA, automatically those here well, lost their jobs, declined drastically, therefore one of them, we want to find what
\end{abstract}

\footnotetext{
${ }^{1}$ Local Government's Revenue and Expenditure Budget
}

kind of a new form of role, that was one of the backgrounds of that spending review.”

Based on the script above, it can be seen that spending review is an adaptive response from actors both inside the Budget Implementation Directorate and Directorate General of Treasury in finding a new role to maintain the organization unit's existence. This confirms the statement made by the Former Director General of Treasury, Agus Suprijanto, as follows:

“... For the Treasury itself, by taking part in or taking spending review as the core business, since spending review is part of budget, it will continue to exist, always needed. The output of this spending review is needed for planning. Hence, we make this a part of APBN cycle: planning, execution, monitoring, spending review, accountability reporting, then replanning. When we have been part of a cycle, we continue to exist. That is the advantage we never thought of before. At least, the PA Directorate (Budget implementation) is not liquidated, rather it becomes even stronger since its output is much anticipated by its customers." (Treasury Indonesia Edisi I/2013)

Informant 2 reiterates that the addition of function and authority of spending review for Budget Implementation Directorate as an adaptive response to the Ministry of Finance's institutional transformation, as follows:

“...its core businesses remain regulations, and monev. Monitoring and evaluation. This Monev include spending review.”

Based on the transcript above, it can be seen that the addition of function and authority of spending review is part of the ways to "save" the organization's existence. However, judging from the institutional construction and supporting elements, the appointment of the Directorate General of Treasury through Budget Implementation Directorate to implement the spending review is indeed reasonable. It is considered that the Directorate General of Treasury is more objective than other institutions, because the Directorate General of Treasury masters the data. Insofar the Directorate General of Treasury performs the distribution process of APBN, hence he/she knows best about the data on expenditure allocation and realization.

Under the Circular Letter of Director General of Treasury Number SE-12/PB/2016 on 
Spending Review Drafting, spending review also involves the Regional Office of Directorate General of Treasury, particularly Budget Implementation Guidance I Field. The addition of role played by Regional Office of Directorate General of Treasury to participate in the spending review drafting at regional level is a follow-up stipulated in the Ministerial Regulation of Finance Number 169/PMK.01/2012 concerning the Organization and Procedure of Vertical Institution of Directorate General of Treasury. One of important points of this regulation is the revitalization of role of Regional Office of Directorate General of Treasury which will have a more strategic role as a form of treasury function optimization and at the same time the representation model of Ministry of Finance in regions. The tasks and functions of Regional Office of Directorate General of Treasury become more varied, including Spending Review Drafting at each region. It just confirms that spending review plays some role in strengthening the institutional function of Directorate General of Treasury.

\section{The Development of Spending Review in the Future}

Currently, the type of review performed by the Directorate General of Treasury is still the functional review. According to Robinson's (2014) classification, functional review is termed as efficiency review. Efficiency review focuses on the suitability between input and the achieved output. The results of review will show the inefficiency level of expenditure of a Ministry/State Institution. Informant 2 explains this focus on efficiency review as follows:

“...We took one step at a time. Currently, we are still struggling with... what do you call that, e... the small ones first. For example, when we look at RKA-KL, we first look at its allocation, is it too much than the standard cost? Then is it odd or not or its allocation is too much or not? For example, this activity is it too much or not. We are still at a level which.. well we are still at that level. Then, we move up again, we begin to compare for example Working Units $\mathrm{A}$ and $\mathrm{B}$ and $\mathrm{C}$. Which one is better, which one is more efficient. Later, the most efficient one will be some kind like a benchmark. It can be a model for others.”

The functional review is currently used by the Directorate General of Treasury despite the possibility to develop it towards a strategic review. Pollitt (2010) defines strategic review as prioritizing the strategies and procedures for saving which allow the government to reduce the portion or even remove the entire budget of a program for it is proven ineffective and, on the other hand, the government may add the portion of other programs' budgets for they are proven more effective in giving benefits for the society. This definition from Pollitt (2010) describes the possibility of an organization unit to lose its existence when through the strategic review process a fact is found that an organization cannot actually give the expected outcome.

The former Director General of Treasury, Agus Supriyanto, in his interview with the Editorial crew of Treasury Magazine (Edition I/2013 issue March 2013) also states that strategic review can have incredible impacts, where the most fundamental one is that a reform may occur to an ministry. In the most extreme one, a ministry could even lose its function. The rationale is that an organization unit with neither contribution nor outcome do not need to exist for it will only waste the state finance, hence it needs to be reformed by merging it with others or liquidating it. It happens because every organization unit in a system must produce something. Even this something it produces should be needed by the society. When this product is not needed, it becomes wasteful. When an organization unit receives some budgets but fails to produce something, then this organization unit does not need to exist, hence it should be removed.

About the possible application of strategic review, Informant 2 explains as follows:

\begin{abstract}
"About strategic review at the most e... in other countries it may be possible to even remove a program (from an organization unit) like that. But we are in Indonesia, so no I don't think so. We would not take that risk. At the most we would say, well for this time being we say is it efficient or not. Is its target right or not. Its allocation, is it too small or too much. But to go that far as to remove (an organization unit) I don't think so. Because in our country the politic is, well it has some influence. We could not do that."
\end{abstract}

Informant 1 also explains as follows:

"In terms of strategic review, we just give recommendation on what the government should do, and what the government should 
not do. When the consequence involves removing an organization unit, it can be. Because the rule is that what the government ought not or should not do."

Using the concept as explained in the transcripts above, the application of strategic review is indeed risky. At least, it could create some resistance from the objects under review. Furthermore, the historic memory related to the removal of a governmental organization unit, such as the removal of Department of Information (or Departemen Penerangan) during the reign of President Gus Dur still haunt some people. Therefore, Informant 1 gives another perspective in relation to the development of spending review in the future, with the following explanation:

\section{"...hence this spending review in Indonesia does not merely pursue the targets of how many are saving, how many are inefficient, how much is the outcome, how much is the impact, rather spending review, in my humble opinion, serves as tools for structure reform. How we can change the mindset of govern- ment behaviours?"}

Based on the transcript above, the benefits which can be offered through this spending review process can actually be more fundamental. It is about changing mindsets, changing behaviors, of course the ones related to government expenditure management. And, at the end of the day, it changes the paradigm of state financial management. Informant 1 continues his explanation as follows:

"Now, that's why it is the (state) financial management paradigm that we are trying to target (with spending review). So, we do not just say, well this is inefficient, well this should not necessarily be done by the government. We talk about what we are doing with this spending review, what we pursue is not what developed countries do. These developed countries are good, alright this is inefficient, well the outcome of this is not (achieved) hence the government should do a,b,c,d.., rather in Indonesia we cannot do that. For what reasons? We are still building the foundation. The foundation of better financial management. What is the better ones? Earlier, Reasonable Without Execption or Wajar Tanpa Pengecualian (WTP) in my opinion is not an indication that the financial management is good. People need to just spend, most importantly they have the receipts, the evidence is there then boom it's WTP. However, what we pursue should be beyond WTP. Even successfully obtaining WTP status, the Ministry of Village still suffers (from bribery case in KPK). Now, with this spending review we expect we can eliminate it, that's the paradigm. Because when we work it is based on the outcome, we work based on the impact, we work to get some output, hence the government expenditures will be actually credible.”

\section{Institutionalization Process of Spending Review}

Upon their participation in OECD Senior Budget Officials Network on Performances and Results conference in Paris in November 2011, the delegation of Directorate General of Treasury made a report and recommendation related to spending review to the Finance Minister (Agus Martowardojo). The Finance Minister welcomed these report and recommendations. He then instructed the implementation of spending review in Indonesia along with special message: "Just begin with the simple yet concrete ones and there has to be something done". This was the beginning of institutionalization of spending review by the Directorate General of Treasury (Treasury Indonesia Edisi I/2013). It is this message which became the starting point of the institutionalization process of spending review by Directorate General of Treasury.

Institutionalization process then is performed by the Directorate General of Treasury, using the following systematic steps:

\section{1) Harmonization of Legal Bases and Imple- mentation Provision}

As a new norm, spending review requires legal bases and implementation provisions. At the beginning of institutionalization process, the Director General of Treasury issued Circular Letter Number SE-37/PB/2012 on Crash Program Review of Budget Implementation Year 2012 and Budget Absorption Projection of 2013 Budget Year. This Circular Letter provides guidelines for drafting the review of expenditure implementation for 2012 Budget Year and Budget Absorption Projection for 2013 Budget Year. In this case, the spending review was implemented in a simple way with its object being the data of one hundred and seven working units in ten Ministries/State Institutions. 
The harmonization of legal bases is done by aligning the Circular Letter Number SE-37/PB/ 2012 on Crash Program Review of Budget Implementation Year 2012 and Budget Absorption Projection of 2013 Budget Year with Ministerial Regulation of Finance Number 169/ PMK.01/2012 concerning Organization and Procedure of Vertical Institution of Directorate General of Treasury. In PMK No. 169/PMK.01/ 2012 the authority of Regional Office of Directorate General of Treasury to participate in the drafting of spending review at regional level is stated.

The implementation of spending review for each year was later on performed in reference to the following provisions:

a. Circular Letter Number SE-37/PB/2012 on Crash Program Review of Budget implementtation Year 2012 and Budget Absorption Projection of 2013 Budget Year. This Circular Letter governs the implementtation provisions of pilot project of spending review.

b. Circular Letter No. SE-3/PB/2013 on Amendment of Circular Letter Number SE-37/PB/ 2012 on Crash Program Review of Budget Implementation Year 2012 and Budget Absorption Projection of 2013 Budget Year.

c. Letter of Director General of Treasury Number S-809/PB/2013 dated January 31, 2013 concerning Circular Letter of Director General of Treasury Number SE-3/PB/2012 and Determination of Object of Expenditure Review Implementation. This letter specifies the addition of review objects from ten Ministries/State Institutions earlier to twenty Ministries/State Institutions.

d. Circular Letter of Director General of Treasury Number SE-54/PB/2013 concerning Technical Guidelines and Report Preparation of Budget Implementation Review and Spending Review of 2013 as the guideline in preparing report of 2013 Budget Implementation Review and Spending Review.

e. Circular Letter of Director General of Treasury Number SE-02/PB/2015 on Spending Review Drafting of 2015

f. Circular Letter of Director General of Treasury Number SE-12/PB/2016 on Spending Review Drafting

g. Letter of Director General of Treasury Number S-10840/PB/2016 dated December 28, 2016 concerning Time Frame of Spending
Review Drafting of 2017 and Addition of Measuring Instruments/Norms of Efficiency.

\section{2) Institutional Infrastructure Arrangement}

There are two reasons why spending review is rightfully performed by the Directorate General of Treasury. Firstly, the Directorate General of Treasury has some expertise in dealing with data on budget implementation and is intensively involved with the working units of Ministries/State Institutions in the daily budget implementation process through a fund disbursement mechanism. Secondly, the institutional structure of Directorate General of Treasury has included thirty Regional Offices throughout Indonesia. Hence, in the effort of institutionalizing spending review, the right steps to be taken are to strengthen the coordination between the Budget Implementation Directorate as the coordinator of spending review implementation and all of their Regional Offices and to strengthen the information technology infrastructure, particularly in relation to the development of application which facilitates the spending review implementation.

\section{3) Preparation of Human Resources (HR)}

The Directorate General of Treasury has the adequate potential HR capacity and an organizational structure which will allow the spending review to be implemented in an institutionalized manner. In terms of its preparation in the institutionalization process, this $\mathrm{HR}$ can be divided into two groups. Firstly, the HR in the Budget Implementation Directorate as the executor of central government expenditure review at central level. The preparation of $\mathrm{HR}$ in the Budget Implementation Directorate is relatively easier since this HR is centered in Jakarta, hence its coordination and information access is easier. Secondly, the HR in each Regional Office of Director General of Treasury. The preparation of HR in Regional Office of Directorate General of Treasury is relatively harder since it is spread to thirty regions throughout Indonesia. To deal with this, the steps taken should be as follows:

a) Transferring officials of Echelon IV (section chief) to whom the Sections in Regional Offices of Directorate General of Treasury related to tasks and functions of spending review will report. Credible personnel with knowledge basis on spending review shall be 
distributed to the thirty Regional Offices throughout Indonesia.

b) Establishing technical teams at each Regional Office of Directorate General of Treasury, by prioritizing the recruitment of workers qualifying several criteria, such as having educational backgrounds in Economics, Accounting, Management, Administration, or Statistics, and having the ability to operate spreadsheet software and statistical data processing software. The provisions on the establishment of this technical team are contained in Circular Letter Number SE-37/PB/2012 on Crash Program Review of Budget Implementation Year 2012 and Budget Absorption Projection of 2013 Budget Year which are the implementation provisions of pilot project of spending review implementation.

\section{4) Development of Scope and Methodology}

The spending review methodology implemented by the Directorate General of Treasury develops dynamically. It is true, particularly, when it deals with thematic review, the object of which depends on the government need. In 2017 Budget Year, the spending review methodology is developed to measure the efficiency of government expenditures for electricity, buildings and constructions as well as the procurement of motor vehicles. This methodology development is also aligned with the government's visions and mission.

\section{Institutionalization of Spending Review from New Institutional Theory Perspective}

Meyer and Rowan (1977) suggest that the existence of an organization is highly dependent on the public trust that this organization is a legitimate and worth-supporting entity. To manifest such an existence, the organization tends to be adaptive to external or social expectation surrounding its existence (DiMaggio and Powell, 1983). In the institutionalization process of spending review, the Directorate General of Treasury as a public organization indicates an adaptive response to the external expectation surrounding it. The spending review ideas, concepts, and practices which have been implemented by other countries give some influence and then they are learned. Upon such learning, the method is independently developed to match the organization's needs.
The preliminary initiation of spending review which began with OECD Conference showed how external pressure forms an understanding that spending review is improtant and beneficial. Former Director General of Treasury, Agus Suprijanto, who attended the conference acknowledges that the spending review explained by OECD was highly attractive and he believed it can be used for the same thing in Indonesia with different goals.

The influence from OECD, from both the explanations presented in the conference and the ideas contained in OECD Journal On Budgeting, was then proven to be initial trigger for the institutionalization of spending review in Indonesia. The Informant 1's statement below explains this:

"It was from 2011 OECD meeting. Those who
were present there, some of them were from us.
Well, we were represented. From then on they
merely endorsed that spending review was
required to make the state expenditure efficient.
Well, it was then brought to Indonesia. When we
got our hands on it, we worked on its methodology
ourselves. Because during the OECD report,
someone just said "Well, it seems we needs
spending review."

Based on the explanation and transcript above, Informant 1 does suggest that the spending review method was independently prepared by those actors in the Directorate General of Treasury. However, the influence of OECD indicates a symptom of coercive isomorphism. Coercive isomorphism constitutes an institutionnalization process which occurs as a result of either formal or informal pressures received by an organization. This pressure comes from either other organizations or cultural expectations from the surrounding society where the organization is established.

The institutionalization of spending review by the Directorate General of Treasury cannot be separated from the institutional transformation of Ministry of Finance. Upon the implementation of institutional transformation of the Ministry of Finance, its organizational structure is demanded to be more fit for purpose and effective. This is to allow the organizational construction within the Ministry of Finance to function effectively and efficiently in aligning their visions and mission and integrating their organizational strategy plan. This results in the shift or removal of an organization unit's authority. Within the budgeting context, the authority for planning and implementing budgets 
is separated. The process of DIPA drafting and DIPA revision which previously involve the Budget Implementation Directorate under the Directorate General of Treasury is handed over to the Directorate General Anggaran (DJA). This has led the Budget Implementation Directorate to lose most of its main tasks and authority functions. According to new institutional theory, this is a form of pressure from the power of regulations reforming the institution of Ministry of Finance. In this case, the existence of the Budget Implementation Directorate depends on its ability to respond to their circumstances. It turns out that the Directorate General of Treasury as the parent of the Budget Implementation Directorate can accurately formulate a new form of authority tasks and functions which can maintain their organization's existence, i.e. by institutionalizing spending review. This fact shows a symptom of coercive isomorphism in the institutionalization process of spending review, where an organization receives some pressure of forcible and binding natures from the regulations of law.

The institutionalization process of spending review by the Directorate General of Treasury which was implemented after many countries have practiced it earlier allows a mimetic isomorphism to take place. DiMaggio and Powell (1983) state that mimetic isomorphism occurs when an organization imitate the practices existing in other organizations they think are better and successful. The mimetic factors in the institutionalization process of spending review by the Directorate General of Treasury are indeed not the main factors. These mimetic factors play their roles of providing supports and complementing the coercive urge which has been there earlier. This is seen in the Informant 1's transcript below:

"Now, that's why it is the (state) financial management paradigm that we are trying to target (with spending review). So, we do not just say, well this is inefficient, well this should not necessarily be done by the government. We talk about what we are doing with this spending review, what we pursue is not what developed countries do. These developed countries are good, alright this is inefficient, well the outcome of this is not (achieved) hence the government should do a,b,c,d.., rather in Indonesia we cannot do that. For what reasons? We are still building the foundation. The foundation of better financial management.
The motivation from the Finance Minister as the top leader of the Ministry of Finance to institutionalize spending review is an embodiment of normative isomorphism symptom. The Finance Minister wanted an improved professionalism in the institution he led, including in terms of APBN management. This effort to improve the professionalism in institution was also seen in the internalization process of spending review to the review technical executor at both central and regional levels. This is proven by the administration of technical guidance or bimbingan teknis (bimtek) and education and training or pendidikan dan latihan (diklat) provided by the Budget Implementation Directorate for the review executing officers.

The institutionalization process of spending review also occurs because of endogenous factors, where the actors in the organization, in this case the Directorate General of Treasury, reinterpreted the influence of foreign elements or recontextualization. According to Lippi (2000), these endogenous factors cause the institutionalization process to be of bottom-up nature or called as Isomorphism. The Isomorphism symptoms occur thanks to the wish of those actors within the Directorate General of Treasury to not only comply with regulations, but also to fulfill the organization's needs as well. The compliance with the provisions of regulations of law and fulfillment of organization's needs are no longer of top-down nature, rather it has been a bottom-up one for it has been adjusted to the circumstand and ability of these actors within the Directorate General of Treasury.

\section{CONCLUSION}

The institutionalization $f$ spending review in the budgeting system in Indonesia is an effort to improve the government expenditure quality in the APBN structure. Spending review discusses the technical aspects in APBN implementation and tries to identify any saving options which can be implemented through budget, and produces inputs for remedy of budgeting planning in the following Budget Year. Spending review is a method of measuring the performance of budget with an emphasis on value for money principle.

The institutionalization process of spending review is influenced by coercive isomorphism factors as can be seen in two things. Firstly, there is some influence from OECD in the preliminary 
initiation of spending review. Secondly, the coercive factors occur when the Directorate General of Treasury as the parent of the Budget Implementation Directorate take some steps as a response to the removal of some Budget Implementation Directorate's authorities due to the implementation of institutional transformation of the Ministry of Finance by formulating the new form of authority tasks and functions which can maintain the organization's existence, i.e. by institutionalizing spending review. This coercive factor is strengthened by mimetic isomorphism which occurs since the institutionalization process of spending review by the Directorate General of Treasury is implemented after many other countries in the world have practiced it. This allows the Directorate General of Treasury to look at and learn the processes other countries have dome, even though they are not abruptly imitated or emulated. The Directorate General of Treasury learns the practices in other countries, then adjust them with their organization's characteristics and needs as well as the objectives to be reached.

The institutionalization process of spending review is also influenced by normative isomorphism factors in the form of the urge to improve the professionalism of the Directorate General of Treasury organization as the executing officers of APBN. This organization's professionalism improvement is also manifested by the administration of technical guidance and education and training for review technical executors at central and regional levels. The institutionalization process of spending review, in addition to being influenced by three isomorphism symptoms is also influenced by endogenous factors which causes the institutionalization process to be of bottom-up nature or called as Isomorphism. The actors within the Directorate General of Treasury reinterpret the influence of foreign elements or recontextualize it

This research without a doubt has its own limitation, particularly because it is conducted using qualitative approve with only one object, i.e. the Regional Office of Directorate General of Treasury of East Java Province. Therefore, its results cannot be generalized in the context of other regions in Indonesia. Based on this limitation, it is then imperative to study similar issues in other regions in Indonesia. Additionally, the use of other approaches, such as quantitative approach or even mixed research method is highly recommended in order to obtain the results which can confirm the findings of this research or even find new findings (Sofyani and Akbar, 2013; 2015).

\section{REFERENCES}

Adhikari, P., C. Kuruppu and S. Matilal. 2013. Dissemination and institutionalization of public sector accounting reforms in less developed countries: A comparative study of the Nepalese and Sri Lankan central governments. Accounting Forum, 213-230.

Agasisti, T., M. Arena, G. Catalano, and A. Erbacci. 2015. Defining spending reviews: a proposal for a taxonomy, with applications to Italy and the UK. Public Money \& Management, 35, 423-430.

Amirya, M., A. Djamhuri and U. Ludigdo. 2011. Pengembangan Sistem Anggaran dan Akuntansi Badan Layanan Umum Universitas Brawijaya: Perspektif Institusionalis. Jurnal Akuntansi Multiparadigma, 3 (3), 343-501.

Arikunto, S. 2006. Prosedur Penelitian Suatu Pendekatan Praktik. Jakarta: PT. Rineka Cipta.

Basuki 2016. Metode Penelitian Akuntansi Dan Manajemen Berbasis Studi Kasus. Surabaya: Airlangga University Press.

Brugnon, G. P. N. 2013. Public engagement practices in spending review processes of the UK, Italy and France.

Dimaggio, P. and W. W. Powell. 1983. The iron cage revisited: Collective rationality and institutional isomorphism in organizational fields. American Sociological Review, 48, 147-160.

Hawkesworth, I. and K. Klepsvik. 2013. Budgeting levers, strategic agility and the use of performance budgeting in 2011/12. OECD Journal on Budgeting, 13, 105-140.

Hawley, A. 1968. Human Ecology. International Encyclopedia of Social Sciences. L. NY: Mancmillan, 328-337.

Heller, M. P. S. 2005. Understanding fiscal space, International Monetary Fund.

Jones, G. R. 2001. Organizational Theory Text and Cases. New Jersey: Prenctice Hall International Inc.

Keputusan Presiden (Keppres) Nomor 20 Tahun 2015 tentang Tim Evaluasi dan Pengawasan Realisasi Anggaran Pendapatan dan Belanja Negara dan Anggaran Pendapatan dan Belanja Daerah. 
Lippi, A. 2000. One theory, many practices. Institutional Isomorphism in the managerialist reorganization of Italian local governments. Scandinavian Journal of Management, 16, 455-477.

Meyer, J. W. and B. Rowan. 1977. Institutionalized Organizations: Formal Structure as Myth and Ceremony. American journal of sociology, 83, 340-363.

Nurdiwaty, D., A. Djamhuri and A. Kamayanti. 2014. Institusionalisasi Akuntansi Sosial Pada Perum Perhutani Blitar. El Muhasaba: Jurnal Akuntansi, 5, 75-101.

Parhusip, B. 2017. Analisis Implementasi Spending Review pada Kementerian Negara/Lembaga Tahun 2013-2015. Kajian Ekonomi dan Keuangan, 20, 191-211.

Pollitt, C. 2010. Cuts and reforms-Public services as we move into a new era. Society and Economy, 32, 17-31.

Pollitt, C. and G. Bouckaert. 2004. Public management Reform: A Comparative Analysis. USA: Oxford University Press.

Rahmayanti, Y. 2013. Spending Review dan Perbaikan Pengelolaan Keuangan Publik. Treasury Indonesia. Jakarta: Ditjen Perbendaharaan.

Robinson, M. 2014. Spending reviews. OECD Journal on Budgeting, 13, 1C.

Saputro, T. I. 2015. Spending Review 2015. Treasury Indonesia. Edisi I/2015 ed. Jakarta: Ditjen Perbendaharaan.

Schick, A. 2009. Budgeting for Fiscal Space. OECD Journal on Budgeting, 9, 7.

Sofyani, H. and R. Akbar. 2013. Hubungan Faktor Internal Institusi dan Implementasi Sistem Akuntabilitas Kinerja Instansi Pemerintah (SAKIP) di Pemerintah Daerah. Jurnal Akuntansi dan Keuangan Indonesia, 10, 184-205.

Surat Direktur Jenderal Perbendaharaan Nomor S-809/PB/2013 tanggal 31 Januari 2013 hal Surat Edaran Dirjen Perbendaharaan Nomor SE-3/PB/2012 dan Penetapan Obyek Pelaksanaan Reviu Belanja.

Surat Direktur Jenderal Perbendaharaan Nomor S-10840/PB/2016 tanggal 28 Desember 2016 perihal Time Frame Penyusunan Spending Review Tahun 2017 dan Penambahan Alat Ukur/Norma Efisiensi.

Surat Edaran Direktur Jenderal Perbendaharaan Nomor SE-02/PB/2015 tentang Penyusunan Spending Review Tahun 2015.
Surat Edaran Direktur Jenderal Perbendaharaan Nomor SE-54/PB/2013 tentang Petunjuk Teknis dan Penyusunan Laporan Review Pelaksanaan Anggaran dan Spending Review Tahun 2013 sebagai pedoman dalam penyusunan laporan Review Pelaksanaan Anggaran dan Spending Review 2013.

Surat Edaran No. SE-3/PB/2013 tentang Perubahan Atas Surat Edaran Nomor SE37/PB/2012 tentang Crash Program Review Pelaksanaan Anggaran Tahun 2012 dan Proyeksi Penyerapan Anggaran Tahun Anggaran 2013.

Surat Edaran Nomor SE-37/PB/2012 Tentang Crash Program Review Pelaksanaan Anggaran Tahun 2012 dan Proyeksi Penyerapan Anggaran Tahun Anggaran 2013.

Wardhana, W., Y. S. Hadi, A. Y. Kapriadi, R. A. Sapari, and A. Nawawi. 2014. Postur APBN Indonesia, Direktorat Penyusunan APBN DJA Kemenkeu RI.

Wijaya, A. H. C. and R. Akbar. 2013. The Influence of Information, Organizational Objectives and Targets, and External Pressure towards the Adoption of Performance Measurement System in Public Sector. Journal of Indonesian Economy and Business: JIEB, 28, 62.

Yin, R. K. 2013. Case Study Research: Design and Methods, USA: Sage publications. 